International Journal of Engineering \& Technology, $7(4.38)(2018) 201-204$
International Journal of Engineering \& Technology
SPC

\title{
Anti-Depopulation Policy as a Method for Boosting Russia's National Security
}

\author{
Julia Vladimirovna Gnezdova ${ }^{1}$, Vasiliy Iosifovich Deren ${ }^{1}$, Elena Nikolaevna Rudakova ${ }^{2}$, \\ Irina Vladimirovna Karapetyants ${ }^{2}$, Anastasia Anatolievna Safronova ${ }^{2}$ \\ ${ }^{1}$ Smolensk State University, Przhevalsky St., 4, Smolensk, 214000, Russia \\ ${ }^{2}$ Russian University of Transport, Obraztsov St., 9, Bldg. 9, Moscow, 127994, Russia \\ *Corresponding author E-mail: gnezdova932780@mail.ru
}

\begin{abstract}
This paper makes a case for that declines in population size must be counteracted via a well-substantiated anti-depopulation policy. Russia's current anti-depopulation policy has yet to live up to its potential. The linkage between depopulation and social/economic processes taking place across the Russian Federation may well be associated with the nation's rather inhomogeneous, polarized naturalterrain, territorial-economic, and settlement structure and marked differentiation in terms of major demographic and natural/economic determinants. By its subject matter, the issue of depopulation has long stopped being strictly scientific - it now also has a political, economic, and ethnocultural ring to it. In this context, 'The Concept on Demographic Policy in the Russian Federation for the Period through to 2025' expressly sets out the goals, principles, objectives, and key focus areas for Russia's demographic policy, as well as the mechanisms for implementing it and curbing depopulation. However, all these postulates have thus far failed to be a factor for rational activity and greater responsibility for implementing set objectives on the part of relevant public authorities, which is affecting the nation's geopolitical security.
\end{abstract}

Keywords: population reproduction, depopulation, causes of depopulation, geopolitical security, anti-depopulation policy.

\section{Introduction}

The global community is currently characterized by a major increase in population size. At the same time, a number of nations are exhibiting a trend toward depopulation, a special trend that poses a threat to the process of reproduction of the nation's population. The Soviet government was taking certain measures to ensure the proper reproduction of its population, but those measures proved insufficient for maintaining the process in a climate of changes in the overall economic situation in the country [1]. As a result, there emerged a trend toward declines in the birth rate, and starting in 1992 Russia's population began to reduce, which started to jeopardize the potential for the use of the nation's rich resources and, along with other factors, posed a threat to its geopolitical security and altered its population geography [2]. The diversity of causes behind depopulation and their interpretations require identifying the key characteristics of this phenomenon in Russia's recessionary economy [3] and relevant ways and factors for improving the situation. The purpose of this work is to provide a scholarly rationale for the use of certain methodological and theoretical approaches to assessing demographic processes in Russia and examine some of the similarities and differences among these processes in Russia and in other advanced nations, where the objective picture of what is really going on and key factors behind depopulation are being obfuscated by boosts in the number of migrants coming into the country.

\section{Methods}

The study involved collecting, reviewing, and systematizing a set of Russian and foreign instances of relevant phenomena and processes, which helped detect a general trend toward declines in the birth rate and increases in the mortality rate in various countries, a trend that is little dependent on their social/political set-up and some other characteristics, even though it is closely linked to their policies and issues related to their security [4]. The study's methodological basis is grounded in the systemic approach, cause-and-effect analysis, logical/mathematical modeling, and some other methods. Its theoretical basis is works by leading Russian and foreign researchers and specialists in the area of economic theory and demography. Of the greatest relevance to the study is the commonality of global population reproduction processes and their special nature in Russia, where, for instance, the rate of declines in natality is comparable to that in the world's richest countries and the rate of increased mortality - to that in the world's poorest countries [5]. That being said, brain-drains are not compensated for by immigration. The findings from this study have helped identify some of the most acute problems in the nation's current and anticipated demographic situation and determine some of the key focus areas for anti-depopulation policy as a major area for ensuring the nation's geopolitical security. 


\section{Results}

\subsection{Retrospective Analysis of the Demographic Situation around the World and in Russia}

An analysis of the data in Table 1 indicates that in the long run the size of the world's population is constantly growing but is doing so unevenly, which, in the authors' view, is also associated with demographic processes being directed differently in different countries. The world's superpowers are posting drops in birth and mortality rates, which is directing the process of reproduction of their population toward depopulation, while in most of the former colonies there are persisting high levels of mortality and natality [6], which has prompted certain scholars to exploit the "threat" of global overpopulation and attribute labor migration or population flight from poor countries that are being bombed to irrational reproduction [7].

Table 1: Change in the Share of the Russian Population in the Global Population between 1800-2050 (based on factual data and projections)

\begin{tabular}{|l|c|c|c|c|c|c|c|c|}
\hline & 1800 & 1900 & 1985 & 1990 & 1992 & 2000 & 2016 & 2050 \\
\hline $\begin{array}{l}\text { Population of } \\
\text { the world, } \\
\text { million people }\end{array}$ & 978 & 1,650 & 4,836 & 5,264 & 5,479 & 6,057 & 7,433 & 9,332 \\
\hline $\begin{array}{l}\text { Population of } \\
\text { Russia, million } \\
\text { people }\end{array}$ & 26.7 & 71.1 & 142.8 & 147.7 & 148.3 & 145.0 & 146.3 & 104.0 \\
\hline $\begin{array}{l}\text { Share of the } \\
\text { Russian } \\
\text { population in } \\
\text { the global } \\
\text { population, \% }\end{array}$ & 2.7 & 4.3 & 2.95 & 2.8 & 2.7 & 2.4 & 1.97 & 1.1 \\
\hline
\end{tabular}

Note. Compiled based on data from the United Nations and Russian statistics yearbooks [8]

Throughout Russia's history (except for periods of war), its population has grown continually. More specifically, in 1719 Russia had 15.8 million people, in 1897 - 128.2 million, in 1917 171.8 million, and in 1990 - over 280 million. In the period from 1917 to 1990, the population of the Russian SFSR grew from 90 to 148.3 million people [5].

An analysis of the geographic structure of trends in the reproduction of Russia's population in the period 1927-2016 helps identify a set of special forms of manifestation of this process in different time periods:

- a demographic explosion, when there is a sharp drop in mortality rates, while there persist high natality levels (as was the case in the period 1927-1930 and 1949-1961);

- a demographic spring, when there persist high natality and natural population increase levels (1935-1940);

- a period of demographic maturity, when relatively minor birth and mortality levels are observed (1966-1988);

- a demographic lull, when natality levels are close to mortality levels (1989-1991);

- a demographic crisis (1992-2012), characterized by mortality rates prevailing over natality levels (Figure 1), which is known to have facilitated depopulation, exacerbated threats to the nation's geopolitical security, and resulted in the emergence of the so-called "Russian Cross" trend in 1992.

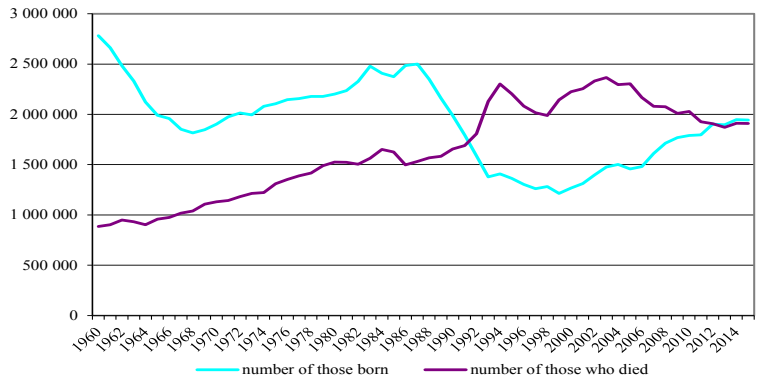

Fig. 1: Russia's natality and mortality rate dynamics in the period 1960-2016 [9]

\subsection{Trends of Demographic Processes Gravitating Toward Depopulation}

Estimates indicate that, after reaching a maximum (about 2\%) in the $1960 \mathrm{~s}$, the rate of annual increase in the world's population started going down. It is now a little over $1 \%$ and is projected to be less than $1 \%$ by 2050 . The total population of the world is, likewise, expected to reach a maximum (nearly 7.5 billion people), and after that it will start decreasing. Depopulation is now a concern with almost all advanced nations, especially those within Europe. Based on data from the United Nations, Europe's population accounted for $26 \%$ of the global population in 1900 and $12.3 \%$ in 2000 and is projected to account for just $7 \%$ in 2050 [10].

Starting in 1992, concurrently with the commencement of revolutionary transformations, depopulation began in Russia as well [11]. Based on official data, in the period 1992-2013 31.3 million Russians were born and 44.6 million passed away. In the period from 1970 to 1990 , Russia's population increased by 17 million, while between 1990 and 2012 it decreased by 5.2 million, which is comparable to the population of 5-6 regions similar to Smolensk Oblast. Despite the immigration process prevailing significantly over the emigration one and Crimea (2.3 million residents) joining Russia in 2014, between 1992 and 2016 Russia's population decreased from 148.3 to 146.5 million people [9].

Depopulation is caused by direct (mortality prevailing over natality) and indirect reasons. Here are just a few indirect causes of depopulation in Russia: the Russian government mainly pursuing a monetarist policy and paying little attention to social/economic processes; social and other tensions, especially among the employable portion of the population as a result of revolutionary transformations in the country, which is causing a lack of confidence in tomorrow, major spikes in illnesses and mortality among those representing the employable portion of the population specifically; growth in poverty rates and declines in the quality of nutrition (e.g., starting in 1990, the average Russian has cut down on the consumption of eggs, meat, dairy products, etc.) [8]; high levels of consumption of harmful products and counterfeit medication; declines in the caliber of healthcare services and these services being charged for, which has seriously affected the health of many Russians (as of 1991, over a third of all newborn children are born sick or fall ill shortly after, with primary disease incidence among children aged below 14 having risen 2 times and 2.5 times among those aged 15 to 17 [12]; unprecedentedly numerous external causes of mortality at play in peacetime, including traffic accidents, fires, and other disasters; the nation's revenues and wealth being distributed in an unfairly uneven manner, which, according to data from the Russian Academy of Sciences, has engendered in a major portion of the Russian people social aggression and social apathy, resulting in the emergence of a social environment that is external to $85 \%$ of Russians (one supplemented by a crisis of morality, increased selfishness, and a lack of psychological confidence in tomorrow), which is hardly suited to human living and is now regarded as the 
primary cause of mortality due to cardiovascular diseases, which, for instance, in Great Britain are the cause of about 200 deaths per 100,000 people, as opposed to 860 in Russia [1].

\subsection{Development and Implementation of Anti- Depopulation Policy in Russia}

Depopulation may be counteracted through anti-depopulation policy - a system of interdependent measures and rational activities by the state and its regions aimed at boosting birth and life expectancy rates, as well as working out a well-thought-out migration policy to facilitate the rational use of the nation's economic resources and ensure its geopolitical security. This kind of policy must be developed and implemented based on research and recommendations from top research institutes, above all the Russian Academy of Sciences. In this context of population reproduction, a major role will be played by the training of a highly qualified workforce specializing in the area. In developing and implementing this kind of policy, it helps to take account of the fact that boosts in natality facilitate the rejuvenation of the nation's population, while boosts in life expectancy may lead to its aging, which going forward may result in depopulation. Therefore, in stimulating both, it may help to adopt a system of measures and activities that are aimed at facilitating the prevalence of boosts in natality over growth in the life expectancy rate.

Anti-depopulation policy in Russia ought to incorporate the following tactical and strategic measures and activities: stimulating research in the area of human population and training relevant manpower for this; boosting economic growth and, above all, economic development rates; improving people's living standards and pursuing sharp declines in differentiation on this indicator; reinstating free education and free healthcare and enabling families to put their kids in various developmental institutions and send them to summer camps; ensuring the maximum engagement of children in extracurricular activity in hobby groups, sports groups, and amateur talent groups, which will facilitate the rational use of free time and the all-round development of children and help free up more time for parents to let them relax and enjoy their favorite avocations or take care of other important business.

Anti-depopulation policy ought to also incorporate measures and activities that imply support for the institution of family: stimulation of growth in birth rates; provision of added support for families every time a child is born in them; creation of appropriate conditions for the employment of women with little children, including organization of free vocational training and retraining for them; creation of appropriate conditions for boosting people's life expectancy; improvement of the population's reproductive health through early detection and proper treatment of illnesses and enhancement of preventive and diagnostic/treatment care; creation of conditions for the self-actualization of youth; protection and enhancement of working conditions; prevention of injuries and combating external factors for mortality, including traffic accidents, which have become a serious problem in Russia recently.

\section{Discussion}

A key component of anti-depopulation policy is a rational migration policy - the use of direct and indirect instruments for regulating external and internal migration. The implementation of this kind of policy is of special significance for Russia, which at the very outset of revolutionary reforms turned (following the dissolution of the Soviet Union and sharp spikes in emigration) into one of the world's top donors of population to other countries, with, based on various estimates, as many as 20 to 30 million of the country's citizens finding themselves on foreign soil all of a sudden and in an instant. Based on data from the Center for Strategic Research, as many as 18 million Russian citizens left the country during the post-Soviet period (compared with 1.5 to 3 million in the period 1918-1924) [13]. In this regard, migration policy ought to be aimed not at helping businesses obtain cheap manpower but at preventing depopulation, rejuvenating and improving the health of Russia's united nations, and stimulating the immigration and reemigration of Russian speaking people into Russia, especially highly intelligent youth. It is the attraction of youth with a decent education and a relevant command of foreign languages that the world's top superpowers are currently directing their anti-depopulation policy toward. The higher the level of education and the more prestigious the educational institution where it was acquired, the higher the likelihood one will be able to immigrate into those countries. At the same time, the superpowers are restricting entry for citizens of "disobedient" states, with entry denied to members of certain political parties, persons with certain medical conditions, as well as those with bad reputation, including those from neighboring states. There are certain best practices related to the implementation of anti-depopulation policy in advanced countries that could be employed with confidence in Russia as well.

A crucial focus area in this kind of policy is stimulating the attraction into Russia of sought-after specialists and prominent scientists, even though this may require substantial expenditure to set up relevant labs with competently selected teams, organizing the placement of orders by enterprises and the state for solutions generated by these labs, and ensuring social comfort - proper social/economic and living conditions for personnel, etc.

Also of importance is the ability to rationally direct internal migration amongst the Russian population and stimulate the attraction of manpower into the country's regions rich in economic and natural resources, especially into Russia's Asian part $(75 \%$ of the country's territory), which is currently experiencing a major population exodus, with less than $20 \%$ of Russians still left in the region. This is one of the reasons the world's top superpowers are demanding unimpeded access to the riches of Siberia and the Far East, which the Russian government is "incapable of reclaiming". A significant role in implementing anti-depopulation policy can and should be played by mass media, the cinema, the theater, and other cultural sectors, which are expected to promote healthy lifestyles, suggest and popularize the best ways and forms of preparing youth for family life, draw attention to the best historical and present-day experience in terms of cultivating and bolstering the institution of family as the essential form of living and working harmoniously, help establish the place and role of children and parents in the family, foster positive interrelationships between generations, explore the genealogical "trees" of famous large families, and raise awareness about the importance of good sanitation and hygiene practices, especially among youth [14].

It, thus, will be worth directing toward the implementation of antidepopulation policy the scientifically substantiated activity of all of the nation's sectors and spheres, which will facilitate the rational and effective development of the domestic economy, the strengthening of the institution of family, boosts in birth and life expectancy rates, and the creation of a favorable social/economic environment conducive to a balanced life for everybody. The primary focus is expected to be on combating depopulation and ensuring Russia's geopolitical security.

\section{Conclusion}

Despite the passage by the Supreme Council of the Russian Federation of Resolution No. 4182-1 'On Taking Urgent Measures to Explore the Population and the Demographic Prospects of the Russian Federation' back in 1992 (with the emergence of the Russian Cross trend), the Russian government began to give due attention to issues of depopulation only after 2000. In 2001, the government adopted 'The Concept on Demographic Development in the Russian Federation for the Period through to 2015', which 
was replaced in 2007 by 'The Concept on Demographic Development in the Russian Federation for the Period through to 2025'. In addition, in 2003 the government adopted 'The Concept on the Protection of the Health of Healthy Citizens in the Russian Federation", and in 2006 it signed into law 'The State Program for Facilitating the Voluntary Resettlement of Compatriots Living Abroad to the Russian Federation'. In 2012, instead of the Concept on the Development of Healthcare, which had been intended to be adopted in 2009, the government signed into law a new program - 'The Development of Healthcare in the Russian Federation State Program'. Similar official documents have been adopted in Russian regions as well.

These and other official documents expressly set out the goals, principles, objectives, and key focus areas for Russia's demographic policy, as well as the mechanisms for implementing it and curbing depopulation as a threat to Russia's national security. However, evidence from practice indicates that these postulates have thus far failed to be a factor for rational activity and greater responsibility for implementing set objectives on the part of relevant public authorities. And that is what has prompted specialists at the Russian Academy of Sciences to predict a new wave of depopulation in Russia in the near future.

\section{References}

[1] L'vov DS (2006), Akademik D.S. L'vov ob ograblenii Rossii [Academician D.S. L'vov on the robbing of Russia]. Russkiy vestnik, 13-20 February, available online: http://www.rv.ru/content.php3?id $=6155$, last visit: 28.10 .2018 .

[2] Buchanan PJ (2013), The death of the West: How dying populations and immigrant invasions imperil our country and civilization. New York: St. Martin's Press.

[3] Krugman PR, Obstfeld M (2007), International economics. Theory and policy. Boston: Addison-Wesley.

[4] van den Brink J (2009), Government and family: Influence or intrusion? A comparative study on family policies in an international perspective. Gouda: Guido de Bres Foundation.

[5] Deren VI (2016), Mirovaya ekonomika: Uchebnoe posobie [The global economy: A study guide] (5th ed.). Smolensk: Izdatel'stvo SmolGU.

[6] Smith A (2009), Issledovanie o prirode $i$ prichinakh bogatstva narodov [An inquiry into the nature and causes of the wealth of nations]. Moscow: Eksmo.

[7] Perkins J (2006), Confessions of an economic hit man: The shocking story of how America really took over the world. London: Ebury Press.

[8] Rossiiskii statisticheskii ezhegodnik [Russian statistics yearbook] (2017), Federal State Statistics Service. Moscow. www.gks.ru/free_doc/doc_2017/year/year17.pdf

[9] Naselenie Rossii: Chislennost', dinamika, statistika [Russia's population: Size, dynamics, statistics] (2018). http://www.statdata.ru/russia

[10] Demchenko TG (2003), Demograficheskii potentsial Rossii y usloviyakh globalizatsii [Russia's demographic potential in a climate of globalization]. Rossiiskii Ekonomicheskii Zhurnal, 1, 7684.

[11] Decree of the President of the Russian Federation 'On Signing into Law the Concept on Demographic Policy in the Russian Federation for the Period through to 2025' (as amended by Decree of the President of the Russian Federation No. 483 of July 1, 2014), available online: http://docs.cntd.ru/document/902064587.

[12] Nekipelov AD, Ivanter VV, Glaz'ev SYu (2013), Rossiya na puti $k$ sovremennoi dinamichnoi i effektivnoi ekonomike [Russia on its way to a modern, dynamic, and effective economy]. Moscow, http://www.ras.ru/FStorage/Download.aspx?id= 8723ae9d-383c-4404-b602-e17eab2c5b88

[13] Smolin ON (2016), Kollegi, ne pora li nam podumat' o zamene vodolazov na nastoyashchikh kapitanov ekonomiki? [Sirs, isn't it about time we started thinking about replacing divers with real captains of the economy?]. http://www.pkokprf.ru/ news/view/30770

[14] Girard A, Roussel L (1982), Ideal family size, fertility, and population policy in Western Europe. Population and Development Review, 8(2), 323-345. 